\title{
Erratum to: Incidence of malignancy in adult patients with rheumatoid arthritis: a meta-analysis
}

Teresa A. Simon ${ }^{1 *}$, Adam Thompson ${ }^{1}$, Kunal K. Gandhi ${ }^{1}$, Marc C. Hochberg ${ }^{2}$ and Samy Suissa ${ }^{3}$

It has come to our attention that, in our recently published article on the incidence of malignancy in adult patients with rheumatoid arthritis [1], the risk of melanoma requires additional clarification. Indeed, the metaanalysis of the risk of melanoma among patients with rheumatoid arthritis compared with the general population showed a standardized incidence rate ratio of 1.23 (95\% confidence interval 1.01, 1.49). This finding was erroneously included in the list of malignancies for which there was no consistent trend in risk among patients with rheumatoid arthritis versus the general population. Instead, with our current, updated meta-analysis it should be considered that there is now a suggestion of a possible increased risk for melanoma. With respect to the Discussion section of our article, we would like to note that the summary standardized incidence ratio shows a modest increased risk for melanoma.

\begin{abstract}
Author details
${ }^{1}$ Bristol-Myers Squibb, Princeton, NJ, USA. ${ }^{2}$ Departments of Medicine and Epidemiology and Public Health, University of Maryland School of Medicine, Baltimore, MD, USA. ${ }^{3}$ Division of Clinical Epidemiology, McGill University, Montreal, QC, Canada.
\end{abstract}

Received: 5 April 2016 Accepted: 6 April 2016

Published online: 04 May 2016

\section{Reference}

1. Simon T, Thompson A, Gandhi K, Hochberg M, Suissa S. Incidence of malignancy in adult patients with rheumatoid arthritis: a meta-analysis. Arthritis Res Ther. 2015;17:212. doi:10.1186/s13075-015-0728-9.

\footnotetext{
* Correspondence: teresa.simon@bms.com

Adam Thompson and Kunal K. Gandhi: Affiliation at time of submission of manuscript.

'Bristol-Myers Squibb, Princeton, NJ, USA
}

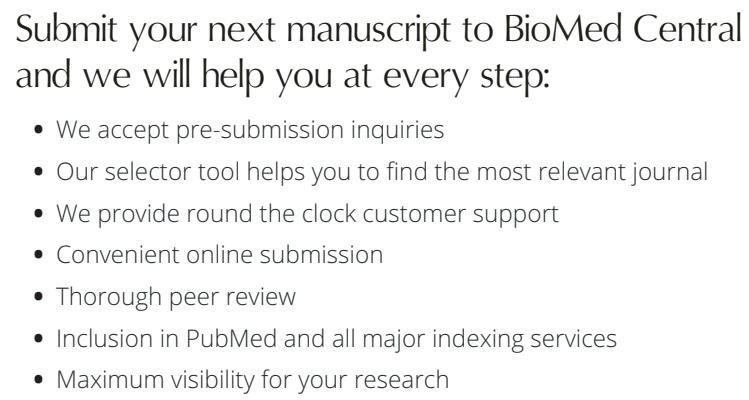

Submit your next manuscript to BioMed Central and we will help you at every step:

- We accept pre-submission inquiries

- Our selector tool helps you to find the most relevant journal

- We provide round the clock customer support

- Convenient online submission

- Thorough peer review

- Inclusion in PubMed and all major indexing services

- Maximum visibility for your research

Submit your manuscript at

www.biomedcentral.com/submit \section{西}

